BOŽICA SLAVKOVIĆ, stipendista

Institut za savremenu istoriju

UDK 316.7(497.1:496.5)"1945/1948"

Beograd, Trg Nikole Pašića 11

$327(497.1: 496.5) " 1945 / 1948 "$

\title{
JUGOSLOVENSKO-ALBANSKA SARADNJA U OBLASTI KULTURE, NAUKE I PROSVETE 1945-1948*
}

\begin{abstract}
APSTRAKT: Članak se bavi saradnjom Jugoslavije i Albanije u sferi kulture, nauke i prosvete tokom 1945-1948, sprovođenjem planova koji su postojali u tim oblastima, pre svega razmenom iskustava i stručnjaka. Rad se zasniva na istraživanjima u Arhivu Jugoslavije i odgovarajucoj literaturi.
\end{abstract}

Ključne reči: Jugoslavija, Albanija, kultura, nauka, prosveta, saradnja, ugovori

Saradnja Jugoslavije i Albanije, započeta posle oslobođenja, bila je vidljiva u svim sferama, naročito na političkom, ekonomskom i kulturnom polju. ${ }^{1} \mathrm{U}$ okviru "neraskidivog“ bratstva i prijateljstva između dve zemlje trebalo je raditi na širenju kulture i jezika jugoslovenskog naroda u Albaniji, kao i razmenjivanju iskustava. Albanija je u kulturnom pogledu bila zaostala zemlja, sa više od polovine nepismenih stanovnika. ${ }^{2}$

U Jugoslaviji je od 8. februara 1946. poslove iz oblasti kulture i umetnosti obavljao Komitet za kulturu i umetnost, a radi usklađivanja i pomaganja rada republičkih ministarstava prosvete bio je osnovan Komitet za škole i nauku. U okviru oba komiteta postojala su odeljenja za veze sa inostranstvom i obavljanje kulturnih i prosvetnih aktivnosti sa drugim

* Rad je deo projekta Srpsko društvo u jugoslovenskoj državi u 20. veku: između demokratije i diktature (177016), koji finansira Ministarstvo prosvete, nauke i tehnološkog razvoja Republike Srbije.

${ }^{1}$ Više o ovome: B. Slavković, Jugoslovensko-albanski ekonomski odnosi 1945-1948. Planovi i saradnja, Istorija 20. veka, 1/2012, Beograd 2012; M. Pavlović, Albania between Tito and Stalin, The Balkans in the Cold war, Belgrade 2011; V. Dedijer, Jugoslovensko-albanski odnosi 1939-1948, Beograd 1949, M. Perović, Ekonomski odnosi Jugoslavije i Albanije (19471948), Beograd 1951; M. Komatina, Enver Hodža i jugoslovensko-albanski odnosi, Beograd 1995.

${ }^{2}$ Arhiv Jugoslavije (dalje AJ), Komisija za međunarodne odnose i veze - Albanija, ACSKJ, IX, 1/II-74, kutija 7. 
zemljama. Komitet za kulturu i umetnost je prestao sa radom 11. decembra 1948, kada je spojen sa Komitetom za škole i nauku u Ministarstvo za nauku i kulturu Vlade FNRJ. ${ }^{3}$

Jugoslavija je odmah posle priznanja albanske države otpočela saradnju sa njom. ${ }^{4}$ Prvo albansko Narodno pozorište je razvijeno zahvaljujući finansijskoj podršci Jugoslavije i pomoći Bože Nikolića koji je boravio u Albaniji od marta do oktobra $1945 .{ }^{5}$ Nikolić je trebalo da organizuje profesionalno pozorište od najboljih amatera, jer je pozorište bilo „diletantsko“ i bez glumica. Neizgrađenom ukusu albanske publike najbolje su odgovarali komadi "folklornog i revolucionarnog" tipa. Nikolić je odlučio da izdvoji najbolje diletante i da, posle Omladinskog kongresa, spremi predstavu Đido za otvaranje pozorišta. Đido je tip „narodnog komada sa pevanjem“ ${ }^{6}{ }^{\mathrm{U}}$ početku je repertoar zavisio od prevođenja pozorišnih dela, pa je Nikolić u međuvremenu dao da se prevede komedija Narodni poslanik Branislava Nušića. Predlagao je da se na prvu predstavu pozovu delegati iz svih prefektura i napiše nekoliko članaka, a takođe i da se izvede nekoliko predstava za običnu publiku, vojsku, đake i besplatne za sirotinju. ${ }^{7}$

Saradnja je uspostavljana i na književnom polju. Već 5 . jula 1945, u Društvu kulture u Tirani održano je književno veče na kome je jugoslovenski književnik Branko Ćopić govorio o temi „Jugoslovenska književnost u NOB-u" istakavši vidnu ulogu pisaca u borbi protiv fašizma. Profesor Aleksa Buda je tom prilikom recitovao jednu Ćopićevu pesmu. ${ }^{8}$

U oktobru 1945. osnovano je u Tirani Društvo za kulturnu saradnju Albanije sa Jugoslavijom i sa prve sednice upućen je telegram Josipu Brozu Titu u kome je podvučeno „bratstvo" albanskog i jugoslovenskog naroda. Za predsednika društva izabran je ministar finansija, pukovnik Ramadan Čita$\mathrm{ku}$, a za sekretara postavljen profesor Aleks Buda. ${ }^{9}$ Istog meseca osnovan je Savez albanskih književnika, kome je bio cilj da poveže sve albanske pisce u jednu organizaciju. ${ }^{10} \mathrm{Na}$ otvaranju doma kulture u Elbasanu, decembra 1945, sekretar Saveza albanskih književnika Dimitar Šuteriki, koji se upra-

${ }^{3}$ Ivan Hofman, Komitet za kulturu i umetnost pri Vladi FNRJ, Ustanova i njena arhivska građa, Arhiv, 2/2001, Beograd 2001, 42-49.

${ }_{5}^{4}$ Jugoslavija je bila prva država koja je priznala Albaniju, 29. aprila 1945.

${ }^{5}$ AJ, Komisija za međunarodne odnose i veze - Albanija, ACSKJ, IX, 1/III-36, kutija $14,1945$.

${ }^{6}$ Dashnori (Đido) - devojački čedan mladić koji se pretvara u hajduka, u krvavog osvetnika kada na njegovu slobodu udari neprijatelj.

${ }^{7}$ AJ, Komisija za međunarodne odnose i veze - Albanija, ACSKJ, IX, 1/III-36, 25. mart-15. oktobar 1945 .

${ }^{8}$ AJ, Tanjug, 112-787, 5. jul 1945.

${ }^{9}$ AJ, Tanjug, 112-789, oktobar 1945.

${ }^{10}$ AJ, Tanjug, 112-789, oktobar 1945. 
vo vratio iz Beograda, opisivao je oduševljenje jugoslovenskog naroda zbog proglašenja albanske republike. ${ }^{11} \mathrm{U}$ listu Baškimi isticane su dobre strane kulturne saradnje Jugoslavije i Albanije. ${ }^{12}$

Jugoslavija je izdvajala stipendije da bi omogućila pripadnicima obeju zemalja da se školuju, davala je materijalna sredstva za uzajamne posete pojedinaca i naučnih, prosvetnih, fiskulturnih, sindikalnih, omladinskih, književnih i umetničkih grupa. ${ }^{13}$ Svi fakulteti su trebali da počnu rad do 1. decembra 1945, a albanske stipendiste su mogli da prime univerziteti u Zagrebu i Ljubljani poštoje Univerzitet u Beogradu bio najviše oštećen. U tom trenutku nisu postojale nikakve mogućnosti za dodelu stipendija. Albanski studenti su se mogli smestiti po studentskim domovima i hraniti po studentskim menzama, ali po cenama koje su važile za jugoslovenske studente ${ }^{14}$ Albanska vlada je želela da pošalje na jugoslovenske univerzitete oko 50 studenata. ${ }^{15} \mathrm{U}$ januaru 1946. ovi studenti su krenuli za Beograd. ${ }^{16}$

Društvo za kulturnu saradnju Jugoslavije i Albanije je 24. marta 1946. na osnivačkoj skupštini u Beogradu usvojilo Nacrt pravila i tom prilikom je određeno da sedište Društva bude u Beogradu. Zadatak Društva bio je da uspostavi što tešnje veze jugoslovenskog i albanskog naroda, pre svega organizovanjem razmene štampe i literature, uzajamnih poseta naučnih, umetničkih, književnih i fiskulturnih radnika i organizacija, propagiranjem i olakšavanjem putovanja radi upoznavanja jedne i druge zemlje, osnivanjem biblioteka i čitaonica, organizovanjem prevoda, priredaba itd. ${ }^{17}$

Albanska vlada je tražila profesore koji bi predavali srpski ili hrvatski jezik u srednjim školama. Odlučeno je da se u albanskim srednjim školama kao obavezni uvedu srpsko-hrvatski i ruski jezik, ali je trebalo da nastavnici znaju italijanski da bi se za početak mogli sporazumeti sa đacima. ${ }^{18}$ Dužnosti profesora srpsko-hrvatskog jezika u Albaniji obuhvatale su i osnivanje i držanje kurseva, širenje jugoslovenske literature, rad na zbližavanju Jugoslavije i Albanije. ${ }^{19}$ U Albaniju je upućeno 8 jugoslovenskih nastavnika. Kako taj broj nije bio dovoljan, Komitet za škole i nauku poslao je još dva profesora (Vojislava S. Dančetovića i Jelenu Dančetović). ${ }^{20} \mathrm{U}$

${ }_{11}^{11}$ AJ, Tanjug, 112-790, decembar 1945.

12 AJ, Komisija za međunarodne odnose i veze - Albanija, ACSKJ, IX, 1/III-37, kutija 14, 1945, Baškimi, br. 243, 244, 11. i 12. oktobar 1945. kutija 14, 1945

${ }^{13}$ AJ, Komisija za međunarodne odnose i veze - Albanija, ACSKJ, IX, 1/III-37,

${ }^{14}$ AJ, Ministarstvo prosvete FNRJ, 313-1-368, 17. novembar 1945.

${ }^{15}$ AJ, Ministarstvo prosvete FNRJ, 313-1-366, 3. novembar 1945.

${ }^{16}$ AJ, Ministarstvo prosvete FNRJ, 313-1-371, 22. januar 1946.

${ }^{17}$ AJ, Komisija za međunarodne odnose i veze - Albanija, ACSKJ, IX, 1/III-38.

${ }^{18}$ AJ, Ministarstvo prosvete FNRJ, 313-1-201, 9. januar 1946.

${ }^{19}$ AJ, Ministarstvo prosvete FNRJ, 313-1-199, 18. decembar 1945.

${ }^{20}$ AJ, Komitet za škole i nauku pri vladi FNRJ, 315-3-360, 27. mart 1946. 
ambicioznim planovima za 1946. godinu bila je i izrada albansko-srpskog rečnika. Albanci su tražili izvesnu količinu ćirilskih slova za štampanje rečnika u Albaniji. Molili su da im se pošalje i jedan tipograf. ${ }^{21}$ Pored Luk Lukaja, duže vremena na rečniku radio je i Nikolajdis Minja (Nikolaj Dismilo), učitelj u Ulcinju. ${ }^{22}$

Jugoslovenski Komitet za kulturu i umetnost je nastojao da ostvari što tešnju saradnju Jugoslavije i Albanije, pa je dosta rađeno na međusobnim posetama i razmenama. Albanski državni hor gostovao je u Rijeci jula $1946 .{ }^{23}$ Očekivalo se da će se koncert u Rijeci isplatiti od prodaje ulaznica, ali publika i lokalni mediji nisu ispoljili gotovo nikakvo interesovanje i dvorana je bila skoro prazna. Albanski hor je odbio da nastupi, ali kako su na brzinu dovedeni učenici lokalne gimnazije i vojnici stacionirani u Rijeci koncert je ipak održan.

Organizatori su smatrali da će izdatke podneti Narodni odbor grada, koji je odobrio još jedan koncert o svom trošku. Iako je drugi koncert ocenjen uspešnim, sa oba koncerta bilo je prikupljeno 26.895 lira. Albanski državni hor je kasnije odlikovan Ordenom bratstva i jedinstva I reda. ${ }^{24}$ Učestvovali su i na Kongresu književnika. Kao albanski predstavnici poslati su Šefćet Musaraja i Sotir Cacija. ${ }^{25}$ Fadil Pačrami, pomoćnik albanskog ministra prosvete, koji u stvari rukovodio Ministarstvom, posetio je Beograd u oktobru 1946. Prema sugestijama Envera Hodže trebalo je da traži jednu bolju štampariju. ${ }^{26}$

Ministar u Tirani smatrao je neophodnim da se iz Jugoslavije šalju knjige, brošure i drugi materijal domovima kulture u Korči, Argirokastru, Sarandi i svim ostalim mestima Albanije. ${ }^{27} \mathrm{U}$ tu svrhu u Tirani je otvorena knjižara „Jugoslovenska knjiga“, preko koje je trebalo snabdevati Albance jugoslovenskom knjigom. ${ }^{28}$ Radi boljeg upoznavanja dve zemlje izlazili su

${ }^{21}$ AJ, Komitet za kulturu i umetnost pri vladi FNRJ, Odeljenje za veze sa inostranstvom, 314-4-15, 20. april 1946.

${ }_{22}^{2}$ AJ, Ministarstvo prosvete FNRJ, 313-1-195, 4. decembar 1945.

${ }^{23} \mathrm{AJ}$, Komitet za kulturu i umetnost pri vladi FNRJ, Odeljenje za veze sa inostranstvom, 314-19-456, 8. novembar 1946.

${ }^{24}$ AJ, Komisija za međunarodne odnose i veze - Albanija, ACSKJ, IX, 1/III-40, 16. avgust 1946 .

${ }^{25}$ AJ, Komitet za kulturu i umetnost pri vladi FNRJ, Odeljenje za veze sa inostranstvom, 314-4-458, 13. novembar 1946.

${ }^{26}$ AJ, Komitet za kulturu i umetnost pri vladi FNRJ, Odeljenje za veze sa inostranstvom, 314-4-13.

${ }^{27}$ AJ, Komitet za kulturu i umetnost pri vladi FNRJ, Odeljenje za veze sa inostranstvom, 314-4-11, 29. jul 1946.

${ }^{28} \mathrm{AJ}$, Komitet za kulturu i umetnost pri vladi FNRJ, Odeljenje za veze sa inostranstvom, 314-4-12, 2. avgust 1946 . 
članci u štampi i priređivane radio emisije na albanskom jeziku „Upoznajmo novu Jugoslaviju“. ${ }^{29}$

U središtu kulturne saradnje Jugoslavije i Albanije bilo je stipendiranje đaka i studenata i školovanje u FNRJ. Smatralo se da će se time unaprediti kulturna saradnja dve zemlje. ${ }^{30}$ Albanska vlada je dodelila albanskim studentima 96 stipendija radi studija na jugoslovenskim univerzitetima. ${ }^{31}$ Komitet za škole i nauku FNRJ odobrio je predložene stipendije $^{32}$ i u decembru 1946. primljeno je u Beogradu 27, Zagrebu 26, Ljubljani 23 i Sarajevu 19 albanskih studenata. ${ }^{33}$ Albanski studenti koji su primljeni na studije na jugoslovenskim fakultetima, a koje je stipendirala FNRJ, bili su raspoređeni po ministarstvima, pa je stanje bilo sledeće: škole na budžetu Ministarstva prosvete dodeljivale su 10 stipendija u iznosu od 2.000 dinara mesečno, mada je tu podrazumevano i onih 5 albanskih studenata koji su već primali stipendije (Filozofski fakultet i Prirodoslovno-matematički fakultet - neograničen broj, Akademija likovnih umetnosti - 5, Hrvatski državni konzervatorijum - neograničen broj, Viša pedagoška škola u Zagrebu - neograničen broj, Viša pedagoška škola u Splitu - neograničen broj studenata). Škole na budžetu Ministarstva industrije i rudarstva - Tehnički fakultet je trebalo da primi srazmerno sve studente koji su se javili iz Albanije. Škole na budžetu Ministarstva narodnog zdravlja dodeljivale su 5 stipendija po 1.500 dinara mesečno (Medicinski fakultet i Farmaceutski fakultet - neograničen broj studenata). Škole na budžetu Ministarstva poljoprivrede i šumarstva davale su za Poljoprivredno-šumarski fakultet 4 stipendije ( 3 za agronomiju po $1.500,1$ za šumarstvo 2.000 dinara) i za Veterinarski 2 po 1.500 dinara (Poljoprivredno-šumarski fakultet - neograničen broj, Veterinarski fakultet - 20 studenata). Škole na budžetu Ministarstva trgovine i opskrbe davale su 4 stipendije po 1.500 dinara (Ekonomsko-komercijalna visoka škola - neograničen broj studenata). Škole na budžetu Ministarstva pravosuđa dodeljivale su 10 stipendija po 1.500 dinara (Pravni fakultet - 100 studenata). ${ }^{34}$

Jugoslovenska strana je nastojala da albanski studenti osete kako su došli u „prijateljsku i savezničku“ zemlju pa je svim ministarstvima naloženo da obaveste svoje područne ustanove u kojima su se nalazili albanski omladinci da im se izađe u susret i sa njima postupa kao sa jugoslovenskim

${ }^{29}$ AJ, Komisija za međunarodne odnose i veze - Albanija, ACSKJ, IX, 1/III-41, 5. novembar 1946 .

${ }^{30}$ AJ, Komitet za škole i nauku pri vladi FNRJ, 315-31-535, 22. jun 1946.

${ }^{31}$ AJ, Komitet za škole i nauku pri vladi FNRJ, 315-6-26, 6. novembar 1946.

${ }^{32}$ AJ, Komitet za škole i nauku pri vladi FNRJ, 315-6-28, 7. decembar 1946.

${ }^{33}$ AJ, Komitet za škole i nauku pri vladi FNRJ, 315-49-229, 10. decembar 1946.

${ }^{34}$ AJ, Komitet za škole i nauku pri vladi FNRJ, 315-49-115, april 1946. 
učenicima. ${ }^{35}$ Ministarstvo prosvete Albanije je odredilo Rizu Hodžu za inspekciju albanskih studenata i učenika u FNRJ. ${ }^{36}$

Razmena iskustava ogledala se i u slanju jugoslovenskih stručnjaka u Albaniju, kao i u primanju njihovih omladinaca na usavršavanje u Jugoslaviji. Albansko poslanstvo je zbog otvaranja Umetničkog liceja (vežbališta) zatražilo da se u Albaniju pošalje 10 jugoslovenskih stručnih muzičara radi učvršćivanja prijateljskih odnosa. ${ }^{37}$ Sekretar Komiteta za kulturu i umetnost Vlado Mađarić je predložio da se pošalje samo 2-3 muzičara, jer je situacija u zemlji bila veoma teška. ${ }^{38}$ Takođe, Ministarstvo kulture primilo je na besplatno usavršavanje i upoznavanje rada 3 mlada glumca iz pozorišne trupe u Tirani. Njihov obrazovni profil bio je veoma nizak, a osim pasoša nisu imali nikakva dokumenta o završenom školovanju. Oni su uslovno upisani u prvi razred Zemaljske glumačke škole u Zagrebu, na osnovu usmenih informacija da je jedan od njih završio pet razreda srednje škole, dok su dvojica imala samo osnovnu. Dogovoreno je da potreban stepen kvalifikacija, od četiri razreda srednje škole, steknu naknadno posle višegodišnjeg boravka u Jugoslaviji. ${ }^{39}$

Osnovni zadatak kulturnog društva Jugoslavija-Albanija bio je popularizacija Albanije u Jugoslaviji i obrnuto. Planirano je da se to ostvari obeležavanjem državnih i drugih značajnih datuma putem štampe, radija, izložbi, akademija, predavanja iz političke, ekonomske i društvene problematike obeju zemalja, izdavanja popularnih brošura, stalne saradnje $\mathrm{u}$ časopisu Albanija i Jugoslavija, razmenama delegacija. ${ }^{40} \mathrm{U}$ toku 1946. Društvo nije imalo uslova da razvije svestranu delatnost u nedostatku prostorija i tehničkog aparata. Rad je bio sveden na obeležavanje albanskih praznika (10. juli - Dan albanske narodne vojske, 28. novembar - Dan zastave) priređivanjem akademija i na organizovanje malog broja predavanja (Vojo Todorović - Albanija u NOB-u, Mila Stojnić - utisci o Albaniji, Boža Nikolić - osnivanje prvog albanskog pozorišta). Rukovodstvo Društva nije bilo kompaktno: na rečima su bili za što tešnje odnose sa Jugoslavijom dok se u svakodnevnom radu osećala tendencija kočenja. Društvo je nastojalo da preuzme kontrolu nad celokupnom kulturnom saradnjom i pored toga što nije imalo materijala i ljudstva da to ispuni. Zabranjivali su rad profesora za

${ }^{35}$ AJ, Komitet za škole i nauku pri vladi FNRJ, 315-49-268, 5. decembar 1946, 31531-553, 10. decembar 1946.

${ }^{36}$ AJ, Komitet za škole i nauku pri vladi FNRJ, 315-49-252.

${ }^{37} \mathrm{AJ}$, Komitet za kulturu i umetnost pri vladi FNRJ, Odeljenje za veze sa inostranstvom, 314-4-185, 14. novembar 1946.

${ }^{38}$ AJ, Komitet za kulturu i umetnost pri vladi FNRJ, Odeljenje za veze sa inostranstvom, 314-4-184.

${ }^{39}$ AJ, Ministarstvo prosvete FNRJ, 313-1-373, 26. januar 1946.

${ }^{40}$ AJ, Komitet za škole i nauku pri vladi FNRJ, 315-20-17, 31. oktobar 1947. 
održavanje tečajeva srpskog jezika van Društva. Društvo je težilo tome da njegova aktivnost bude ograničena samo na intelektualce, a ne i na širi krug ljudi. Predsednik Ramadan Čitaku bio je „prilično šovinistički raspoložen i Kosovar". Fadil Pačrami je nasledio Sejfulu Maleševa koji je bio smenjen kao "trockista“, ali ni on nije bio prijateljski nastrojen prema Jugoslaviji. Takvom radu Društva doprinela je i nedovoljna upornost jugoslovenskih stručnjaka koji su poslati na rad u Albaniju. Podružnice u unutrašnjosti bile su slabo organizovane; u Elbasanu nije proradio kurs srpskog jezika, $\mathrm{u}$ Beratu je priređeno nekoliko predavanja, u Đirokastri je bila slaba posećenost predavanja o Jugoslaviji, u Korči samo jedno predavanje. Kulturnoprosvetni rad se nije omasovio. ${ }^{41}$ Društvo je organizovalo jednu izložbu, okupljalo je ljude koji su igrali šah ili se u bašti igrao ping-pong, svakog drugog ponedeljka se održavalo predavanje za Jugoslovene u Tirani kao i kurs albanskog jezika, mada je posećenost bila mala. Od Komiteta za kulturu i umetnost Društvo je tokom 1947. za uređenje i održavanje prostorija tražilo 230.000 dinara, za reprezentaciju 500.000 i personalne izdatke 100.000, ukupno 830.000 dinara. ${ }^{42}$ Društvu je poslata izvesna količina knjiga, 300 logaritamskih tablica za albanske srednje škole i 2.000 matrica za njihove potrebe. Upućen je profesor za jezik i nađene su prostorije za potrebe društva. ${ }^{43}$

Godina 1947. bila je veoma plodna u kulturnoj saradnji Jugoslavije i Albanije. U Tirani je 9. jula 1947. potpisana Konvencija o međusobnoj kulturnoj saradnji. Sa jugoslovenske strane potpisnik je bio Marijan Stilinović, predsednik Komiteta za škole i nauku, a sa albanske Manol Konomi, ministar dva resora, pravde i prosvete. Dogovoreno je osnivanje profesorskih katedri i postavljanje lektora za jezike, literaturu i istoriju. Države ugovornice mogle su osnivati kulturne ustanove na teritoriji druge države ugovornice. Predviđeno je da ugovornice potpomažu razmenu istraživača, profesora, instruktora, prosvetnih radnika, studenata, đaka, umetnika, predstavnika ostalih profesija u kulturi. Trebalo je regulisati mogućnost polaganja ispita i spremanja naučnih teza; $u$ te svrhe određeno je da se daju stipendije. Države ugovornice su trebale da pomažu najtešnju saradnju naučnih, kulturnih, prosvetnih, sindikalnih, fiskulturnih, umetničkih i sličnih društava, slobodu istraživanja u bibliotekama, arhivama i na terenu, uzajamne posete pojedinaca i izabranih grupa, saradnju sindikalnih, omladinskih i ženskih organizacija. Saradnja se odnosila na razmenu knjiga i časopisa, štampe i publikacija, delatnosti novinskih agencija, razmenu muzejskog i

${ }^{41}$ AJ, Komisija za međunarodne odnose i veze - Albanija, ACSKJ, IX, 1/III-46, jul avgust 1947.

${ }^{42}$ AJ, Komitet za škole i nauku pri vladi FNRJ, 315-20-7.

${ }^{43}$ AJ, Komitet za škole i nauku pri vladi FNRJ, 315-20-20, 1. jul 1947. 
školskog materijala, predavanja i tečajeve jezika, koncerte, izložbe i priredbe, pozorišne predstave, radio, film i slično. Ova konvencija potpisana je na najmanje pet godina. ${ }^{44}$

Jugoslavija je sve više ulagala $u$ Albaniju ne samo $u$ finansijskom već i u stručnom smislu. Radnicima, nameštenicima i službenicima - državljanima FNRJ koji su bili poslati na rad u Albaniju trebalo je i dalje isplaćivati njihovu redovnu platu, pošto upućivanje na rad nije podrazumevalo promene $\mathrm{u}$ njihovom radnom odnosno službeničkom odnosu. ${ }^{45}$ Davana im je poslednja plata u FNRJ, uz 600 franaka zarade od albanskih vlasti. Teškoće su bile $u$ tome što prinadležnosti nisu primali istovremeno u FNRJ i u Albaniji. ${ }^{46}$

Poslanstvo FNRJ tražilo je da se upute u Tiranu profesori koji bi organizovali kurseve srpskog jezika, pomagali rad na izradi rečnika i udžbenika i učestvovali u radu Društva za kulturnu saradnju Albanije i Jugoslavije. Nastavnici su morali biti u prvom redu „politički izgrađeni i odani“, a uz to i sa dovoljno stručnog znanja. ${ }^{47}$

Jugoslovenski nastavnici u Albaniji bili su raspoređeni po većim gradovima: Marjan Zagar u Skadru, Franja Brodnik u Elbasanu i Mirko Bračić u Đirokastru (svi iz Slovenije), Josip Depolo u Beratu i Josip Cagljević u Valoni (iz Hrvatske), Ružica Simić u Korči, Zagorka Filipović, Vojislav i Jelena Dančetović u Tirani (iz Srbije). ${ }^{48}$ Kao nastavnica srpskog jezika na privatnim kursevima poslata je Đurđica Vojinović. ${ }^{49}$

U početku nove školske 1946/47. odlukama Ministarstva prosvete Albanije srpski jezik je ukinut u nekim školama ili je sveden na dva časa nedeljno za više razrede, a za glavni strani jezik usvojen je ruski. Krajem januara ponovo je uvedeno učenje srpskog jezika u Korči i prvi put u Beratu. Tako se srpski jezik predavao u svim albanskim gimnazijama, u dvema kao glavni, a u ostalim kao pomoćni, pored ruskog. Stav Ministarstva prosvete promenjen je pod pritiskom omladine, jer se od 140 učenika 120 izjasnilo za srpski jezik. ${ }^{50}$

${ }^{44}$ AJ, Prezidijum Narodne skupštine 1945-1956, 15-16-284; AJ, Komitet za škole i nauku pri vladi FNRJ, 315-3-575.

${ }^{45}$ AJ, Komitet za kulturu i umetnost pri vladi FNRJ, Odeljenje za veze sa inostranstvom, 314-4-158.

${ }^{46}$ AJ, Komitet za škole i nauku pri vladi FNRJ, 315-3-452, 1. septembar 1947.

${ }^{47}$ AJ, Komitet za škole i nauku pri vladi FNRJ, 315-3-474, 22. april 1947.

${ }^{48}$ AJ, Komitet za škole i nauku pri vladi FNRJ, 315-3-471, 26. mart 1947.

${ }^{49}$ AJ, Komitet za škole i nauku pri vladi FNRJ, 315-3-381, 12. maj 1947.

${ }^{50}$ AJ, Komisija za međunarodne odnose i veze - Albanija, ACSKJ, IX, 1/III-47, 1947. 


\begin{tabular}{|c|c|c|c|c|}
\hline & & $\begin{array}{l}\text { Broj } \\
\text { đaka }\end{array}$ & $\begin{array}{l}\text { Kursevi - broj } \\
\text { tečajnika }\end{array}$ & $\begin{array}{l}\text { Privatni kursevi } \\
\text { - broj tečajnika }\end{array}$ \\
\hline \multirow[t]{7}{*}{ Tirana } & Gimnazija & 175 & 390 & 120 \\
\hline & Učiteljska škola & 40 & & \\
\hline & Pedagoški institut & 60 & & \\
\hline & Tehnički institut & 70 & & \\
\hline & Umetnička škola & 34 & & \\
\hline & Kadetska škola & 165 & & \\
\hline & Večernja škola & 50 & & \\
\hline \multirow[t]{2}{*}{ Elbasan } & Progimnazija & 513 & 30 & 50 \\
\hline & Učiteljska škola & 87 & & \\
\hline Đirokastra & Gimnazija & 138 & & 20 \\
\hline Korča & Gimnazija & 90 & 10 & 30 \\
\hline Valona & Trgovačka škola & 60 & 20 & \\
\hline \multirow[t]{2}{*}{ Berat } & Učiteljska škola & 63 & 20 & 10 \\
\hline & Licej & 30 & & 20 \\
\hline Skadar & Učiteljska škola & 50 & & \\
\hline
\end{tabular}

Na molbu Albanskog poslanstva da se dostave nastavni programi jugoslovenskih fakulteta i visokih škola za potrebe Ministarstva prosvete, poslati su programi za Pravni fakultet, Ekonomsko-komercijalnu visoku školu i Tehnički fakultet. ${ }^{51}$

Komisija za izradu udžbenika srpsko-hrvatskog i albanskog jezika otpočela je rad početkom $1947 .{ }^{52}$ Nastavni savet Ministarstva prosvete NR Srbije odlučio je da se udžbenik srpskog jezika za upotrebu u albanskim školama napiše u Srbiji. Taj posao bio je poveren Henrihu Bariću, odličnom poznavaocu albanskog jezika. ${ }^{53}$ Albansko Ministarstvo prosvete planiralo je da izda udžbenik književnosti slovenskih naroda (ruske, bugarske, jugoslovenske) za gimnaziju. Poslanstvo FNRJ u Tirani tražilo je sličan materijal koji bi Albanci preveli za ovaj udžbenik (političke i kulturne prilike kod jugoslovenskih naroda u prvoj polovini 19. veka, odraz političkih i socijalnih promena na književnost jugoslovenskih naroda, političke i socijalne prilike između dva svetska rata). Predviđeni su i jugoslovenski klasici (Vuk Karadžić, Njegoš i drugi) i predstavnici tadašnje novije književnosti (Nazor, Zogović, Ćopić, Goran Kovačević, Markovski, Cankar). ${ }^{54}$ Tada su u upotrebi u Albaniji za učenje srpsko-hrvatskog jezika bili udžbenik i čitanka, koje je

${ }^{51}$ AJ, Komitet za škole i nauku pri vladi FNRJ, 315-10-2, 23. januar 1947.

${ }^{52}$ AJ, Komitet za škole i nauku pri vladi FNRJ, 315-54-308, 15. januar 1947.

${ }^{53}$ AJ, Komitet za škole i nauku pri vladi FNRJ, 315-54-334.

${ }^{54} \mathrm{AJ}$, Komitet za kulturu i umetnost pri vladi FNRJ, Odeljenje za veze sa inostranstvom, 314-4-40, 27. jun 1947. 
napisala nastavnica Đurđica Vojnović. Udžbenik je bio namenjen Albancima, ali je konstatovano da sadrži dosta nedostataka i grešaka, da je gradivo nesređeno i bez ilustracija. I pored toga, ova skripta se koristila pošto zvaničan udžbenik nije bio štampan. ${ }^{55}$

Za izradu albansko-srpskog i srpsko-albanskog rečnika angažovan je petočlani odbor, u kojem je sarađivao i profesor Dančetović. Rečnik je trebalo da obuhvata 20.000 reči i da se štampa u 70.000 primeraka u Beogradu. ${ }^{56}$ Izgleda da je albansko Ministarstvo prosvete kočilo izdavanje rečnika pošto je srpsko-albanski deo bio završen i dva meseca je stajao u Ministarstvu pod izgovorom da treba da se otkuca. Ubrzano se radilo i na drugom delu rečnika, bez obzira na nezadovoljstvo Ministarstva prosvete njegovim kvalitetom, jer je postojala „velika potreba za njim“. ${ }^{57}$ Štampanje rečnika je potom odloženo za 2-3 meseca pošto je ustanovljeno da mu nedostaje „moderna“ terminologija i da „nema izraza iz SKP (b)-a, ni iz knjiga i članaka jugoslovenskih rukovodilaca". ${ }^{58}$ Ipak, krajem septembra 1948. rukopis rečnika je završen. ${ }^{59}$ Komitet za škole i nauku je u izveštaju o pregledanom rečniku istakao da su u srpsko-hrvatskom postojali krupni nedostaci: veliki broj reči koje su retko upotrebljavane, nedostajale su neke obične reči, a i reči nisu bile akcentovane. U albanskom delu rečnika prevod mnogih reči bio je pogrešan, uzimani su provincijalizmi. Predloženo je da se rečnik da na redakturu Zekeriji Redži (koji je bio član Oblasnog izvršnog odbora Kosovsko-metohijske oblasti), najboljem poznavaocu albanskog jezika u FNRJ. ${ }^{60}$

Jugoslavija i Albanija su sarađivale i na polju muzike i razmene umetničkih trupa. Po nalogu Komiteta za kulturu i umetnost Agata Žic je mesec i po dana boravila u Albaniju da albanskom Komitetu za kulturu i umetnost pomogne $\mathrm{u}$ organizaciji grupa narodnih pesama. ${ }^{61}$ Muzički pedagog i dirigent iz Ljubljane Bojan Adamič bio je u Albaniji radi procene stanja i kvaliteta albanskih muzičara. Njegovi utisci su bili negativni: simfonijski orkestar, koji su činili vojni i civilni muzičari, bio je neusaglašen, jer civili nisu dovoljno poznavali muziku; njihov nivo znanja bio je takav da „nijedan od tih muzičara ne bi mogao da svira ni u kafanskom orkestru“. U Albaniji je postojao samo jedan klavir, a jedini profesor violine $u$ Elbasanu

${ }^{55}$ AJ, Komitet za škole i nauku pri vladi FNRJ, 315-54-350, 13. novembar 1947.

${ }^{56}$ AJ, Komitet za škole i nauku pri vladi FNRJ, 315-54-341, 9 maj 1947.

${ }^{57}$ AJ, Komitet za škole i nauku pri vladi FNRJ, 315-3-468, 1. mart 1947.

${ }^{58}$ AJ, Komitet za škole i nauku pri vladi FNRJ, 315-3-471, 26. mart 1947.

${ }^{59}$ AJ, Komitet za škole i nauku pri vladi FNRJ, 315-54-445, 12. oktobar 1948.

${ }^{60}$ AJ, Komitet za škole i nauku pri vladi FNRJ, 315-54-342.

${ }^{61} \mathrm{AJ}$, Komitet za kulturu i umetnost pri vladi FNRJ, Odeljenje za veze sa inostranstvom, 314-4-41, novembar 1947. 
nije radio ništa od kraja okupacije. ${ }^{62}$ Planiran je tromesečni kurs za horovođe pošto Albanci nisu imali dovoljno sredstava da plate posebnog dirigenta $\mathrm{u}$ te svrhe. Za profesionalnog dirigenta tražio se čovek spreman da se uhvati u koštac sa svim problemima u toj oblasti. Tražio se i profesionalni violinista da bi naučio albanske violiniste tehnici sviranja. Profesor Mile Asić, dirigent koji je dirigovao raznim horovima u Jugoslaviji, upućen je početkom maja 1947. u Albaniju da organizuje hor pri Društvu Albanija-Jugoslavija u Tirani. Ideja o horu potekla je od sekretara Kulturnog društva Albanija-Jugoslavija Nuri Hute. Realizacija je započeta posle njegovog odlaska sa dužnosti i bez organizacionih priprema albanskog Kulturnog komiteta. Asić je samoinicijativno obišao sindikate i omladinske organizacije muzičara i muzičkih škola. U horu sa oko 80 izvođača bilo je malo žena, što je govorilo o niskom stepenu emancipacije albanskog društva. Da bi hor mogao postepeno da uči i da se usavršava, pevale su se pesme jugoslovenskih kompozitora koje su bile jednostavne i dvoglasne. Asić je radio i na organizovanju kursa za dirigente, ali se sa njegovim početkom odugovlačilo. ${ }^{63}$ Angažovao se i na rešavanju deficita kadrova za orkestar Radio Tirane. Tražio je 10 instrumentalista, ali je jugoslovenska muzička scena bila deficitarna u tim kadrovima. On je insistirao na tome da bi na neki način suzbio italijanski uticaj u Albaniji. Uputio je i molbu da mu se pošalju svi jugoslovenski školski planovi vezani za muzičko obrazovanje. Tokom boravka u Sloveniji avgusta 1947. tražio je muzičare koji bi otišli na rad u Albaniju. Konačno, postigao je dogovor sa osmoro slovenačkih i hrvatskih muzičara koje je angažovao za odlazak u Albaniju. ${ }^{64}$

Uslovi zapošljavanja i rada u Albaniji bili su nepovoljni s obzirom na nizak životni standard, kulturno siromaštvo i uticaj politike u svim sferama života. Ugovor o radu je trebalo sklopiti na godinu dana, a podrazumevao je sviranje $\mathrm{u}$ državnom orkestru i predavanje teorije instrumenata. Dirigent je trebalo da predaje ne samo dirigovanje već i teoriju muzike, harmoniju i kontrapunkt. Plata je iznosila 9.000 leka, odnosno dinara, ali su jugoslovenski muzičari imali pravo na dotadašnju platu u svojoj zemlji i na socijalno osiguranje i pravo da se po isteku ugovora vrate $u$ istu službu. ${ }^{65} \mathrm{U}$ Albaniju su poslati klarinetista Josip Pomikalo, Ivan Baksa, Aleksandar Fućkar, violončelista i violinista Ladislav Miranov. ${ }^{66}$ Fućkar je, međutim, povučen zbog

${ }^{62}$ AJ, Komitet za kulturu i umetnost pri vladi FNRJ, Odeljenje za veze sa inostranstvom, 314-19-538.

${ }^{63}$ AJ, Komitet za škole i nauku pri vladi FNRJ, 315-4-31.

${ }^{64} \mathrm{AJ}$, Komitet za škole i nauku pri vladi FNRJ, 315-4-206, 24. februar 1948.

${ }^{65}$ Isto.

${ }^{66}$ AJ, Komitet za kulturu i umetnost pri vladi FNRJ, Odeljenje za veze sa inostranstvom, 314-19-554. 
rđavog ponašanja i vređanja Albanaca i protiv njega je poveden disciplinski postupak. ${ }^{67}$

Uporedo sa traganjem za muzičarima, tragalo se i za muzičkim instrumentima. U FNRJ su se na tržištu jedino mogli naći mali bubanj, mandoline i gitare. Albansko-jugoslovensko društvo za uvoz i izvoz trebovalo je od Jugoslavije 30 komada ,škole za instrumente“ (za klavir, violinu, violu, čelo, klarinet, flautu, trombon, obou), 5 mandolina, 5 gitara i mali bubanj sa rokom isporuke do avgusta $1947 .{ }^{68} \mathrm{U}$ Jugoslaviji su putem Državnog muzičkog magazina nabavljeni novi kao i upotrebljavani muzički instrumenti, a gramofonske ploče preko izdavačkog preduzeća "Prosveta“. ${ }^{69}$ Iz Državnog muzičkog magacina u Beogradu za Albaniju otpremljena je muzička roba u vrednosti od 293.612 dinara. Albanci su tražili 106 različitih instrumenata, od toga najviše violine i klarinete u vrednosti od 355.500 dinara. Komitet za kulturu i umetnost posegao je za otkupom polovne robe koja je potom isporučena Albaniji. ${ }^{70}$

Vid saradnje predstavljala su i gostovanja jugoslovenskih umetnika u Albaniji. Komitet za kulturu i umetnost FNRJ je planirao da pošalje grupu jugoslovenskih umetnika, solista i 20 plesača, na turneju po Albaniji. U budžetu je bilo odobreno 520.800 dinara za troškove gostovanja. ${ }^{71}$ Jugoslovenska umetnička grupa izvela je za 23 dana turneje 17 priredaba i 3 radioemisije, obišavši sve veće gradove u Albaniji. Po mišljenju jugoslovenskog poslanstva u Tirani, turneja je bila uspešna jer je „od naroda bila primljena sa velikim oduševljenjem", ali albanske političke strukture nisu ovu posetu "politički“ dovoljno iskoristile. Komitetu za kulturu i umetnost upućene su primedbe da je grupa bila suviše brojna za albanske pozornice i da ubuduće treba slati manje grupe. ${ }^{72}$

Društvo za kulturnu saradnju Jugoslavije i Albanije, u okviru svojih aktivnosti, pripremalo je i proslavu rođendana Josipa Broza Tita. Oni su želeli da orkestar Radio Tirane uvežba Simfonijsko kolo Gotovca i prve delove Ohridske legende Hristića. ${ }^{73}$

${ }^{67}$ AJ, Komitet za kulturu i umetnost pri vladi FNRJ, Odeljenje za veze sa inostranstvo, 314-4-198, 13. novembar 1947.

${ }^{68}$ AJ, Komitet za kulturu i umetnost pri vladi FNRJ, Odeljenje za veze sa inostranstvom, 314-4-44.

${ }^{69}$ AJ, Komitet za škole i nauku pri vladi FNRJ, 315-4-129, 26. januar 1948.

${ }^{70} \mathrm{AJ}$, Komitet za kulturu i umetnost pri vladi FNRJ, Odeljenje za veze sa inostranstvom, 314-4-15.

${ }^{71}$ AJ, Komitet za kulturu i umetnost pri vladi FNRJ, Odeljenje za veze sa inostranstvom, 314-4-167, 14. februar 1947.

${ }^{72}$ AJ, Komitet za škole i nauku pri vladi FNRJ, 315-4-25, 21. april 1947; videti i Lj. Petrović, Kulturne veze Jugoslavije i Albanije 1946-1948, Istorija 20. veka, 2/2002, 73.

${ }^{73} \mathrm{AJ}$, Komitet za kulturu i umetnost pri vladi FNRJ, Odeljenje za veze sa inostranstvom, 314-4-22, 314-4-23. 
Jugoslavija je u Albaniju, između ostalog, slala slikarski i pisaći materijal. Nabavka slikarskog materijala trebalo je da se podmiri uvozom prema odobrenom planu uvoza Komiteta za kulturu i umetnost. Lak za retuš i učvršćenje na platnu i fiksativ za boje trebalo je da se isporuče preko Ministarstva industrije NR Srbije, a 200 metara slikarskog platna preko Ministarstva industrije NR Hrvatske. ${ }^{74}$ Slikarsko platno je isporučeno u septembru, iako je isporuka bila predviđena za jul 1947. Komitet za kulturu i umetnost bio je stalno u pregovorima sa preduzećima Hempro, Hromos, Sava Zagreb i Šumadija, ali nijedno od ovih uvoznih preduzeća nije se moglo obavezati ugovorom za isporuku i uvoz ostatka slikarskog materijala. Potom je Komitet, u sporazumu sa Jugoslovensko-albanskim društvom za uvoz i izvoz, taj materijal izbrisao sa uvoznog spiska Albanije. ${ }^{75}$ Od preduzeća „Sava“, veletrgovine papira i pisaćeg pribora, u septembru je tražena isporuka, ali je i tu došlo do „određenih“ problema. ${ }^{76}$ Preduzeće je odgovorilo da nema potrebno odobrenje Ministarstva spoljne trgovine za taj uvoz. $^{77}$

Albanske ustanove su tražile literaturu od jugoslovenske strane; Umetnički licej u Tirani bio je zainteresovan za literaturu o slikarstvu i vajarstvu, muzici i pozorišnoj umetnosti. Naročito su im bile potrebne knjige koje su imale istorijski pregled pojedinih grana umetnosti. ${ }^{78}$ Društvo za kulturnu saradnju nezvanično se dogovorilo sa albanskom stranom da se $\mathrm{u}$ Albaniju pošalje tematska izložba "radova sa Pruge". Do novih razgovora o većoj jugoslovenskoj likovnoj izložbi došlo je 1948, kada je potkomisija iz Tirane tražila da se u Albaniju pošalje izložba za 1. ili za 25. maj. U Komitetu su procenili da bi takvu izložbu mogli uputiti tek na jesen 1948. Tada se albanski Komitet obratio Društvu za saradnju Hrvatske sa Albanijom pokušavajući da se sa njima dogovori mimo znanja Komiteta. Izložba je odložena kada je Komitet saznao za nju, uz obrazloženje da u Jugoslaviji u tom trenutku ne postoji dovoljan broj kvalitetnih umetničkih dela pošto se velika likovna izložba umetnosti 19. i 20. veka nalazila na turneji po inostranstvu. ${ }^{79}$

${ }_{75}^{74}$ AJ, Komitet za škole i nauku pri vladi FNRJ, 315-4-128, 16. jun 1947.

${ }^{75}$ AJ, Komitet za kulturu i umetnost pri vladi FNRJ, Odeljenje za veze sa inostranstvom, 314-4-15.

${ }^{76} \mathrm{AJ}$, Komitet za kulturu i umetnost pri vladi FNRJ, Odeljenje za veze sa inostranstvom, 314-4-54.

${ }^{77}$ AJ, Komitet za kulturu i umetnost pri vladi FNRJ, Odeljenje za veze sa inostranstvom, 314-4-66.

${ }^{78} \mathrm{AJ}$, Komitet za kulturu i umetnost pri vladi FNRJ, Odeljenje za veze sa inostranstvom, 314-4-459, 25. februar 1947.

${ }^{79}$ AJ, Komitet za kulturu i umetnost pri vladi FNRJ, Odeljenje za veze sa inostranstvom, 314-4-15, februar 1948. 
Sačuvani su podaci o tome da je Komitet za kulturu i umetnost FNRJ poslao izvesnu količinu knjiga za novootvoreno pozorište u Tirani. ${ }^{80}$ Takođe, $u$ Tiranu je poslat i primerak antologije jugoslovenske poezije. ${ }^{81}$ Komitet za škole i nauku u Tirani tražio je po jednog arheologa i etnografa za uređenje Etnografskog muzeja u Tirani, uz finansiranje albanske vlade. Bili su predloženi Marijana Gušić, etnograf i Stjepan Gunjača, direktor muzeja na Klisu. ${ }^{82}$ Jugoslovenska akademija je predlagala organizovanje ekipe geografa, antropogeografa, etnografa i medicinara koji bi proučavali probleme iz svoje struke u delu između Skadra i jugoslovenske granice. Komitet za škole i nauku se složio sa predlogom i predvideo sumu od 100.000 dinara za ovo putovanje radi geografsko-etnološkog proučavanja terena. ${ }^{83}$

Komitet za kinematografiju vlade FNRJ poslao je u Albaniju filmove Filmskih novosti (od novembra 1946. do januara 1947), 52. i 53. dokumentarni film Albanija (2 kopije), koji su sinhronizovani na albanski jezik. Sovjetski dokumentarni film Jugoslavija od Varlamova bio je takođe sinhronizovan na albanski jezik. Filmske novosti su se redovno sinhronizovale na albanski jezik; sinhronizovani su i dokumentarni filmovi Balkanske igre, Tragom 4. i 5. ofanzive, Mladina gradi. Pravile su se specijalne kopije jugoslovenskih dokumentarnih filmova Tito u Hrvatskoj, Mladost i snaga, U ime naroda, Nova zemlja, Julijska krajina, Nove pobede, ali pošto nije bilo dobrih prevodilaca na albanski jezik taj proces se odužio.

Da bi Filmske novosti objavile scene iz Albanije, poslati su na njihovu inicijativu jedan stalni filmski reporter i jedan pomoćnik. Bili su voljni da po inventarnoj ceni ustupe Albaniji neophodna postrojenja za stvaranje sopstvene filmske proizvodnje manjeg obima, kao i da pošalju 3-4 albanska omladinca u FNRJ da završe kurseve ${ }^{84}$ Albanci su pokazivali interesovanje za jugoslovenski film; posle prikazivanja Slavice, tražili su i film Živjeće ovaj narod. $^{85}$

Školske 1947/48. na jugoslovenskim fakultetima bilo je 70 studenata iz NR Albanije - jugoslovenskih stipendista i oko 200 kao stipendista albanske vlade. ${ }^{86}$ Albanski studenti su bili smešteni u studentskim domovi-

${ }^{80} \mathrm{AJ}$, Komitet za kulturu i umetnost pri vladi FNRJ, Odeljenje za veze sa inostranstvom, 314-19-462.

${ }^{81} \mathrm{AJ}$, Komitet za kulturu i umetnost pri vladi FNRJ, Odeljenje za veze sa inostranstvom, 314-19-531.

${ }^{82}$ AJ, Komitet za škole i nauku pri vladi FNRJ, 315-10-10.

${ }^{83}$ AJ, Komitet za škole i nauku pri vladi FNRJ, 315-54-318.

${ }^{84}$ AJ, Komisija za međunarodne odnose i veze - Albanija, ACSKJ, IX, 1/III-43, 20. februar 1947.

${ }^{85} \mathrm{AJ}$, Komitet za škole i nauku pri vladi FNRJ, 315-3-563.

${ }^{86}$ AJ, Komitet za škole i nauku pri vladi FNRJ, 315-6-66, 17. avgust 1947. 
ma. Visina stipendija varirala je u početku školske godine između 2.5003.000 dinara. Pred kraj školske godine stipendije su izjednačene na 2.500 dinara mesečno. Za 1947/48. Komitet za škole i nauku predvideo je još 100 novih stipendija ${ }^{87}$ Albanski studenti koji su studirali u FNRJ nisu mogli postići željene rezultate, iako su se trudili da uče i daju što više ispita. Najveće teškoće su se ispoljavale u učenju srpskog jezika i u tome što je većina njih došla posle početka školske godine. Da bi se savladale poteškoće u učenju srpskog jezika predlagano je da albanski studenti ostanu u Jugoslaviji i preko letnjeg raspusta i da za to vreme primaju stipendije. ${ }^{88}$

Albanski omladinci na radu i školovanju u FNRJ bili su razmešteni $\mathrm{u}$ preduzećima odnosno stručnim školama koje su spadale $u$ nadležnost resora industrije, rudarstva, saobraćaja, poljoprivrede i šumarstva. Izvestan broj omladinaca zaposlenih u preduzećima koja nisu imala organizovane internate bio je smešten $u$ domove za učenike $u$ privredi koji su se nalazili pod rukovodstvom narodnih odbora. Oni su takođe imali problema sa jezikom, a postojao je i problem sa omladincima koji bi se razboleli do te mere da su bili trajno nesposobni za dalje školovanje, pa su se zbog vraćali $u$ Albaniju. Iz Albanije su upućena 4 referenta, koji su bili namešteni uz albansko poslanstvo sa zadatkom da obilaze omladince i pomažu im u vaspitanju. ${ }^{89}$

Radne akcije su smatrane korisnim i zbog vaspitavanja omladine, a $\mathrm{u}$ obzir su dolazili pre svega oni koji su se isticali u podršci NOP-u. ${ }^{90}$ Izgradnja pruge Drač-Elbasan trebalo je da bude „velika škola za vaspitanje oko 12.000 omladinaca i omladinki“. Predviđeni su kursevi za nepismene, kolektivne čitalačke grupe, dolazak umetničkih i sportskih ekipa. ${ }^{91}$ Osnovano je 35 analfabetskih tečajeva, koje je pohađalo 510 omladinaca; obrazovane su i 53 čitalačke grupe u kojima je učestvovalo 277 omladinaca. ${ }^{92}$

U Tirani je otvoren Pedagoški institut i za lektora srpskog jezika angažovan je profesor Dančetović koji je znao albanski jezik. ${ }^{93}$ Postojao je plan da se Pedagoški institut, koji je imao rang Više pedagoške škole, pretvori u Filozofski fakultet i da se osim srpskog jezika proučava i istorija NOB i literatura Jugoslavije. ${ }^{94}$

Godina 1948. bila je presudna u saradnji Jugoslavije i Albanije. U prvoj polovini godine činilo se da se ništa nije promenilo u odnosima dveju

\footnotetext{
${ }^{87}$ AJ, Komitet za škole i nauku pri vladi FNRJ, 315-49-314, 4. septembar 1947.

${ }^{88}$ AJ, Komitet za škole i nauku pri vladi FNRJ, 315-49-305, 12. jun 1947.

${ }^{89}$ AJ, Komitet za škole i nauku pri vladi FNRJ, 315-31-569,12. mart 1947.

${ }^{90} \mathrm{AJ}$, Komitet za škole i nauku pri vladi FNRJ, 315-4-29.

${ }^{91}$ AJ, Tanjug, 112-807-808, 7. mart 1947.

${ }^{92}$ AJ, Tanjug, 112-809-810, 2. april 1947.

${ }^{93}$ AJ, Komitet za škole i nauku pri vladi FNRJ, 315-54-308, 15. januar 1947.

${ }^{94}$ AJ, Komitet za škole i nauku pri vladi FNRJ, 315-3-495, 15. septembar 1947.
} 
zemalja, mada je još prethodne godine bilo nagoveštaja promena. Tirana je počela da se okreće Moskvi, iako je i dalje insistirano na jugoslovenskoalbanskom bratstvu i jedinstvu. Pojedinci su sabotirali prikazivanje jugoslovenskih filmova. „Jugoslovenska knjiga“ u Tirani nije postigla naročit rezultat. Albanci su najviše kupovali marksističku literaturu, i to samo ako je bila na albanskom jeziku. Uglavnom su tražili literaturu na italijanskom jeziku. Ipak, Jugoslavija je i u tim okolnostima nastavila sa kulturnim i prosvetnim aktivnostima sve dok je to bilo moguće.

U februaru 1948. poslata su u Albaniju tri muzičara, ${ }^{95}$ mada je obećano da će se uputiti njih deset. ${ }^{96}$ Sindikalno umetničko društvo mariborskih železničara „Angel Besednjak“ gostovalo je početkom maja 1948. deset dana u Albaniji, na poziv albanskih sindikata. U Narodnom pozorištu priredili su horsko-instrumentalni koncert sa programom borbenih i narodnih pesama; publici su se najviše dopale pesma „Sloboda“, pesme o Titu, „Oj Kozaro“, „Atil“, „Ribar“, pesma o slovenačkoj omladini i „Konjuh planina“ $\mathrm{u}$ aranžmanu dirigenta Albina Horvata. ${ }^{97}$ Komitet za kulturu i umetnost FNRJ poslao je na turneju po Albaniji grupu od 46 umetnika na čelu sa Veljkom Bijedićem. ${ }^{98}$

Umetnička grupa koja je bila upućena povodom rođendana J. B. Tita u Tirani je održala tri koncerta: prvi je bio svečani, drugi za armiju, a treći za publiku. Albanska štampa se jedva osvrnula na njene priredbe, mada je albanska publika "toplo pozdravljala“ izvođače programa, prilagođenog njihovom ukusu. Poslednji koncert nije bio nigde objavljen tako da je 200 mesta ostalo prazno, što je bilo neuobičajeno za jugoslovenska gostovanja. Dogovor da se održi velika turneja po celoj Albaniji nije ostvaren, a umetnička grupa je posle isplaćenog honorara od strane jugoslovenskog poslanstva vraćena za Beograd. ${ }^{99}$

Smatralo se da je za unapređenje kulturne saradnje Jugoslavije i Albanije potrebno da se prevedu dela M. Miljanova Čojstvo i junaštvo, Mi i Arbanasi, Biografija druga Tita od Radovana Zogovića, Došljaci - pesme Ali

${ }^{95}$ AJ, Komitet za kulturu i umetnost pri vladi FNRJ, Odeljenje za veze sa inostranstvom, 314-4-201, 9. februar 1948.

${ }^{96} \mathrm{AJ}$, Komisija za međunarodne odnose i veze - Albanija, ACSKJ, IX, 1/III-48, 10. februar 1948.

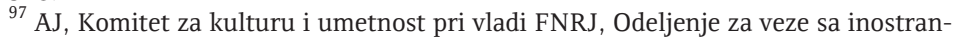
stvom, 314-4-180.

${ }^{98} \mathrm{AJ}$, Komitet za kulturu i umetnost pri vladi FNRJ, Odeljenje za veze sa inostranstvom, 314-19-530

${ }^{99}$ AJ, Komitet za kulturu i umetnost pri vladi FNRJ, Odeljenje za veze sa inostranstvom, 314-4-181, 2. jun 1948. 
Binaka, Skadar na Bojani od istog pisca. ${ }^{100} \mathrm{U}$ Centralnom domu Kulturnog društva Albanije i Jugoslavije otvorena je velika izložba posvećena prvom petogodišnjem planu FNRJ, sa dosta grafikona i fotografija. ${ }^{101}$ Albanski Komitet za kulturu i umetnost tražio je po jednog režisera, koreografa, maskera i dekoratera za izgradnju pozorišta. ${ }^{102}$ Takođe, žalio se na nedostatak programa i tekstova za albanske umetničke institucije i tražio je pozorišni repertoar, repertoar za diletantske pozorišne trupe, repertoar za decu, članke i razne knjige o pozorišnoj umetnosti, programe predmeta za srednje pozorišne škole, muzičke i slikarske tekstove i skripte koji su se upotrebljavali u srednjim muzičkim, pozorišnim i slikarskim školama. ${ }^{103}$

U Albaniji se na radu nalazilo 10 profesora srpsko-hrvatskog jezika. Milentije Stojiljković je postavljen za profesora na Pedagoškom institutu u Tirani. ${ }^{104}$ Ivan Nakić je radio na Višoj pedagoškoj školi, u učiteljskoj školi na večernjoj školi i sa oficirima; bio je nepoželjan među Albancima, jer se postavio „kao neka visoka ličnost“. Dušan Žgonc je bio profesor u Đirokastru; sem u gimnaziji, radio je na oficirskom tečaju, na kursu za profesore, $u$ frontu i sa milicijom. Nije bio stariji od đaka, pa mu je to zadavalo teškoće. Silva Breceljnik je bio profesor na učiteljskoj školi u Beratu. Imao je 18 godina kao i Žgonc, ali je dao bolje rezultate. Vinko Lukić je predavao na višoj pedagoškoj školi, večernjoj gimnaziji, srednjoj školi za geometre, školi za fiskulturu i za oficire; Albanci nisu bili zadovoljni njegovim radom. Đurđica Vojinović je radila u „vojničkoj gimnaziji“, tj. gimnaziji za decu čiji su roditelji pali u ratu i za decu poginulih boraca; pokazala je dobre rezultate. Radmila Simeunović je predavala u srednjoj tehničkoj školi, gimnaziji i srednjoj ekonomskoj školi i bila cenjena u toj sredini. Emilija Katić je predavala u gimnaziji u Draču i pokazala srednje rezultate. Zora Pekić je u industrijskoj školi i na kursevima u Albaniji pokazala dobre rezultate.

Razmišljalo se da se za školsku 1948/1949. obrazuju katedra za albanski jezik i književnost u Skoplju i katedra za srpsko-hrvatski jezik i književnost na Univerzitetu u Tirani. Prosvetnim radnicima Albanije dodeljeno je 10 mesečnih stipendija za boravak u Jugoslaviji tokom školskog raspusta. ${ }^{105}$ Albanskim studentima je trebalo omogućiti upis na fakultete i pored toga što su zakasnili na početak školske godine ili im nisu bila legali-

${ }^{100}$ AJ, Komitet za kulturu i umetnost pri vladi FNRJ, Odeljenje za veze sa inostranstvom, 314-19-482

${ }^{101}$ AJ, Tanjug, 112-828-829, 7. januar 1948.

${ }^{102}$ AJ, Komitet za kulturu i umetnost pri vladi FNRJ, Odeljenje za veze sa inostranstvom, 314-19-555, 22. aprila 1948.

${ }^{103}$ AJ, Komitet za škole i nauku pri vladi FNRJ, 315-19-529.

${ }^{104}$ AJ, Komitet za škole i nauku pri vladi FNRJ, 315-3-423, 18. februar 1948.

${ }^{105}$ AJ, Komitet za škole i nauku pri vladi FNRJ, 315-20-10. 
zovana školska dokumenta. Upis je trebalo sprovesti tako što bi se obuhvatio i zimski i letnji semestar, odnosno priznao bi im se zimski semestar. ${ }^{106}$ Albanska vlada je davala 235 stipendija. U Beogradu: ekonomski fakultet 29 (jugoslovenska vlada 11), pravni fakultet 12 (jugoslovenska vlada 6), filozofski 6 (jugoslovenska vlada 3), prirodno-matematički 2 (jugoslovenska vlada 6), veterinarski 6 (jugoslovenska vlada 1), poljoprivredno šumarski 22 (jugoslovenska vlada 8), škola za filmske glumce i režisere 1-albanska vlada ukupno 78, jugoslovenska vlada 35 stipendija. U Zagrebu: prirodnomatematički 24 (jugoslovenska vlada 3), tehnički 50 (jugoslovenska vlada 16), studije za pozorišne glumce, režisere i scenografe 5 (jugoslovenska vlada 3), akademija likovnih umetnosti 4 (jugoslovenska vlada 3) - ukupno 83 stipendija albanske vlade, a 25 jugoslovenske. U Ljubljani: tehnički fakultet 56 (jugoslovenska vlada 29), muzička akademija 5 (jugoslovenska vlada 3) albanska vlada 61, jugoslovenska 32 stipendije. U Sarajevu: medicinski fakultet 13 (jugoslovenska vlada 8). ${ }^{107}$

Međudržavni ugovori Jugoslavije i Albanije su raskinuti odlukom albanskog političkog vrha 1. jula 1948. kada se Albanija priključila Informbirou. Albansko ministarstvo inostranih poslova predalo je poslanstvu FNRJ dve note: prva, da svi jugoslovenski stručnjaci, savetnici i drugi građani na radu u Albaniji napuste Albaniju u roku od 48 sati, a druga da albanska vlada otkazuje sve privredne sporazume i protokole zaključene između dve zemlje. Albanija tada nije otkazala jedino Ugovor o prijateljstvu i uzajamnoj pomoći. ${ }^{108}$ Zahtev jugoslovenskog Ministarstva inostranih poslova da se jugoslovenski radnici bar prevezu do granice je odbijen, čak su uvedene izlazne vize, koje su se sporo i neažurno dobijale. Nastalo je šikaniranje i onemogućen im je svaki rad. Zatvorena je knjižara „Jugoslovenska knjiga" u Tirani i zabranjena prodaja lista Borba ${ }^{109}$ Poslanstvo iz Tirane javilo je da dela „Brigada“ i „Jamnica“ ne treba slati za prevod, jer Albanci to ne bi primili. Komitet za kulturu i umetnost Albanije čak je vratio i Književne novine, a iz Državne biblioteke su izbačene sve jugoslovenske knjige, pa i prevodi Staljinovih dela. ${ }^{110}$ Albansko ministarstvo je izdalo naređenje da se iz udžbenika izbace svi tekstovi o maršalu Titu; zabranjene su pesme o njemu, na ispitima se nisu smela postavljati pitanja u vezi sa Titom. ${ }^{111}$ Albanski studenti su u domovima počeli da skidaju slike J. B. Tita, otuđili

${ }^{106}$ AJ, Komitet za škole i nauku pri vladi FNRJ, 315-6-72, 31. januar 1948.

${ }^{107} \mathrm{AJ}$, Komitet za škole i nauku pri vladi FNRJ, 315-49-321

${ }^{108}$ AJ, Arhiv Josipa Broza Tita, Kabinet Maršala Jugoslavije, 1-3-v/44, 1. jul 1948, Jugoslavija je otkazala ugovor o prijateljstvu i uzajamnoj pomoći 12. novembra 1948.

${ }^{109}$ AJ, Ministarstvo spoljne trgovine, 1/1-189, 30. jun 1948.

${ }^{110}$ AJ, Komitet za kulturu i umetnost pri vladi FNRJ, Odeljenje za veze sa inostranstvom, 314-4-222, 13. oktobar 1948.

${ }^{111}$ AJ, Predsedništvo Vlade FNRJ, 50-48-105, 3. jul 1948. 
su se i odvojili od jugoslovenskih studenata, u toku diskusija izražavali su solidarnost sa Informbiroom. ${ }^{112}$ Uprkos tome što je Jugoslavija primila oko 700 omladinaca na školovanje i stručno usavršavanje u fabrikama, gde su tretirani kao polukvalifikovani radnici, posle objavljivanja Rezolucije IB-a u Jugoslaviji ih je ostalo samo 7. Mnogi su otišli na jednomesečni godišnji odmor u Albaniju, ali se više nisu vraćali u Jugoslaviju. ${ }^{113}$

$\mathrm{Na}$ taj način završio se period saradnje Jugoslavije i Albanije, mada su nagoveštaji prekida postojali još u 1947. godini. Komitet za kulturu i umetnost i Komitet za škole i nauku nisu uspeli da ostvari svoje planove o saradnji zato što se Jugoslavija nalazila u teškom položaju posle oslobođenja i imala deficitarnost u kadrovima i sredstvima, ali i stoga što Albanija nije bila dovoljno otvorena za jugoslovenske stručnjake. Politika je i ovog puta bila presudna za ostvarivanje saradnje dve države.

${ }^{112}$ AJ, Komitet za škole i nauku pri vladi FNRJ, 315-6-78, 15. avgust 1948, 315-6-79.

${ }^{113}$ AJ. Ministarstvo rada FNRJ, 25-84-213, 8. novembar 1948. 
Božica Slavković

THE SCIENTIFIC, EDUCATIONAL AND CULTURAL COOPERATION BETWEEN THE YUGOSLAVIA AND ALBANIA 1945-1948

\section{Summary}

Relations between Yugoslavia and Albania, after the 1945, were marked with a new dimension: devised the euphoric mood of mutual brotherhood, of the indissoluble friendship and cooperation._Despite the fact that this relation was marked in the political, economic, ideological and military aspect, the article will describe the cultural aspect of this collaboration. It was less known and researched aspect of the cooperation. The Yugoslavia with Albania signed a Treaty of friendship and mutual assistance 1946, and it was resigned for the next two years. A convention on cultural - educational cooperation was signed. That meant first of all efforts in higher education institutions and other institutions for higher education, the foundation professorship chair, placing instructors for language, literature and history. It was full coordination in the cultural and educational work, scholarships for professional training, exchange of students, courses during the holidays. The article examined how plans were implemented and what was the process of the co-operation in these years. Gradual deterioration of the mutual relationship started in 1947, when Albanian political leadership turned to the USSR. The cooperation was terminated in 1948, after the accession of Albania to the Cominform and turn against Tito's Yugoslavia. 